\title{
Kinetic analysis and effect of culture medium and coating materials during free and immobilized cell cultures of Bifidobacterium animalis subsp. lactis Bb 12
}

\author{
Hasan Jalili \\ Department of Food Science, Technology and Engineering \\ Faculty of Biosystem Engineering \\ Agricultural Campus \\ University of Tehran \\ Karaj, Iran \\ Hadi Razavi* \\ Department of Food Science, Technology and Engineering \\ Faculty of Biosystem Engineering \\ Agricultural Campus \\ University of Tehran \\ Karaj, Iran \\ E-mail: srazavi@ut.ac.ir \\ Mohammad Safari \\ Department of Food Science, Technology and Engineering \\ Faculty of Biosystem Engineering \\ Agricultural Campus \\ University of Tehran \\ Karaj, Iran \\ Abdeltif Amrane \\ Ecole Nationale Supérieure de Chimie de Rennes \\ Université de Rennes and \\ Université Européenne de Bretagne \\ France
}

Financial support: Department of Food Science and Engineering Faculty of Agricultural Engineering and Technology University of Tehran.

Keywords: Bifidobacterium, immobilization, kinetic models, medium composition.

Abbreviations: A: growth-associated product formation coefficient (g lactic and acetic acid $\mathrm{g}^{-1}$ biomass)

$\mathrm{B}$ : non-growth-associated product formation coefficient (g lactic and acetic acid $\mathrm{g}$ biomass ${ }^{-1}$ )

f: toxic power for product inhibition

$\mathrm{h}$ : toxic power for biomass inhibition

$\mathrm{K}_{\mathrm{S}}$ : monod constant $\left(\mathrm{g}\right.$ lactose $\mathrm{L}^{-1}$ )

$\mathrm{m}_{\mathrm{s}}$ : maintenance coefficient $\left(\mathrm{g}\right.$ lactose $\mathrm{g}^{-1}$ biomass $\left.\mathrm{h}^{-1}\right)$

$\mathrm{p}$ : lactic and acetic acid concentration $\left(\mathrm{g} \mathrm{L}^{-1}\right)$

$\mathrm{p}_{\mathrm{m}}$ : the maximum product concentration above which bacteria does not product acid

$\mathrm{p}_{\mathrm{m}}$ : the maximum product concentrationa bove which bacteria does not grow $\left(\mathrm{gL}^{-1}\right)$

s: substrate concentration $\left(\mathrm{g} \mathrm{L}^{-1}\right)$

$\mathrm{x}$ : biomass concentration $\left(\mathrm{g} \mathrm{L}^{-1}\right)$

$\mathrm{x}_{\mathrm{m}}$ : maximum biomass concentration

$\mathrm{Y}_{\mathrm{P} / \mathrm{S}}$ : product yield coefficient ( $\mathrm{g}$ lactic and acetic acid $\mathrm{g}^{-1}$ )

$\mathrm{Y}_{\mathrm{X} / \mathrm{s}}$ : biomass yield coefficient ( $\mathrm{g}$ biomass $\mathrm{g}^{-1}$ lactose)

$\mu$ : specific growth rate $\left(\mathrm{h}^{-1}\right)$

$\mu_{\mathrm{m}}$ : maximum specific growth rate $\left(\mathrm{h}^{-1}\right)$

Microencapsulation technique appears helpful for more protection of Bifidobacteria against acid inhibitory effect. The effect of medium composition and product inhibitory in free cell culture, as well as the effect of the coating materials in immobilized cells, on biomass growth, acid production and substrate utilization kinetics of Bifidobacterium animalis subsp. lactis Bb 12 in uncontrolled batch fermentation was examined. The Monod and the Luedeking and Piret equations with a product inhibition term involving toxic power terms improved model efficiency for both growth and production. The model showed that media and coating

*Corresponding author 
materials had an effect on toxic power terms. Cell immobilization had a positive impact on $B$. animalis culture. Kinetic analysis revealed the permeability of the coating material had a major impact on culture parameters; permeability increased in the following way: Gellan xanthan < Alginate chitosan < KCarageenan-locust been, and hence growth parameters $x_{m}$, maximum specific growth rate $\left(h^{-1}\right)\left(\mu_{m}\right)$ and monod constant (g lactose $\left.\mathrm{L}^{-1}\right)\left(\mathrm{K}_{\mathrm{S}}\right)$ followed the same trend as well as the linking between growth and production. The link between the microbial environment and cell growth was highlighted by the model. It was shown that for an increasing protect effect of coating materials against environmental deleterious factors, namely a decrease of the permeability, transport limitation occurred, which was disadvantageous for cell formation.

Owing to the rapid increase concerning the knowledge of intestinal microbiota and modulation factors, interest in supplementing various types of food products with probiotic bacteria has grown significantly. Predominant group of the colonic microflora are bifidobacteria that can account for up to $25 \%$ of the total number of present bacteria (Macfarlane and Macfarlane, 1997). Bifidobacteria are gram-positive, non spore forming, non motile, saccharoclasic and usually catalase-negetive anaerobes with various shapes (Gomes and Malcata, 1999). Bifidabacteria have heterofermentative nature and can degrade carbohydrate to acetic acid and lactic acid as major metabolites through fructose-6-phosphate shunt (van der Meulen et al. 2006). These bacteria have several benefits for their host, like human, such as vitamin production, anticarcinogenic activity immunostimulating effect, lowering the cholesterol level and inhibiting the growth of pathogenic bacteria with shift in intestinal $\mathrm{pH}$ induced by the acidic metabolites during carbohydrate fermentation (Bozanic and Tratnik, 2001; Dunne and Shanahan, 2002). Bifidobacterium animalis subsp. Lactis is one of the most usual industrial strains due to its industrial properties such as tolerance to oxygen and acid resistance (Janer et al. 2005).

Bifidobacteria are fastidious bacteria that require complex and expensive media for propagation, such as MRS medium with the addition of growth promoting factors due to their stringent growth requirements. For this reason these bacteria show poor growth in milk, and hence several substances such as whey permeate and yeast extract have been studied for their potential growth-stimulating activity, with the aim of finding a suitable nutrient supplement to incorporate into culture media (Doleyres et al. 2002; Ghaly et al. 2003; Janer et al. 2004).

Microencapsulation is a process in which cells are retained within an encapsulating matrix or membrane. Microencapsulation of probiotics has been investigated for improving their viability in food products and intestinal tract because microencapsulation leads to better tolerance against high concentration of toxic compounds and toxic loading than free cells (Doleyres and Lacroix, 2005). A variety of polymers, such as alginate, chitosan, locust been gum, K-carageenan, gellan and xanthan have been used to make probiotic microcapsules (Krasaekoopt et al. 2004).

During Bifidobacteria fermentation, accumulated lactic and acetic acids cause media acidification, which inhibit Bifidobacteria growth, leading to an acidification of membrane cytoplasm, which causes inhibition in nutrient transport by motive force collapse (Desjardins et al. 1990; Balannec et al. 2007). To overcome this inhibition, the $\mathrm{pH}$ is maintained during culture at its optimal value for Bifidobacteria growth.

Mathematical modeling is an important tool to optimize fermentation processes. Several studies are available to describe the effect of lactic acid inhibitory effect on growth and acid production in controlled and uncontrolled $\mathrm{pH}$ of lactic acid bacteria (Monteagudo et al. 1997; Altiok et al. 2006; Balannec et al. 2007). However, no model seems to be available in the literature to describe the linking between growth and production rate and the inhibitory effect of organic acids production during uncontrolled $\mathrm{pH}$ fermentation for free and microencapsulated Bifidobacteria.

The purpose of this paper was to (1) investigate the effect of medium composition and product inhibitory effect on kinetics of Bifidobacterium animalis subsp. lactis $\mathrm{Bb} 12$ in uncontrolled batch fermentation. In this aim, for free cell cultivation media three levels of whey permeate was added to skim milk and $10 \mathrm{~g} \mathrm{~L}^{-1}$ yeast extract; (2) examine the effect of microencapsulation and type of coating materials on kinetics of the organism in uncontrolled bath fermentation. Hence Bifidobacterium animalis subsp. lactis $\mathrm{Bb} 12$ encapsulated in alginate-chitosan, k-carrageenanlocust been and gellan-xanthan gums as coating materials and cultivated in complex medium containing whey permeate, skim milk and yeast extract.

\section{EXPERIMENTAL}

\section{Microorganisms}

Bifidobacterium animalis subsp. lactis $\mathrm{Bb} 12$ was obtained from Christian Hansen (HØrsholm, Denmark).

\section{Culture media}

Complex Commercial whey and skim milk powder were supplied by local factory (Zarin Laban Pars, Karaj, Iran) and rehydrated with distilled water to prepare 6 and $10 \%$ total soluble solid solutions respectively. Culture media were prepared from $10 \mathrm{~g} \mathrm{~L}^{-1}$ yeast extract (Sigma-Aldrich UK) and various amounts of these solutions according to Table 1, which showed that rehydrated whey and skim milk, were added to have a total content (the sum of both) of $90 \%$ for the three media used. Therefore, three levels of whey amounts were tested: low (LCWP), medium (MCWP) and high (HCWP) WP concentrations. To avoid any effect 

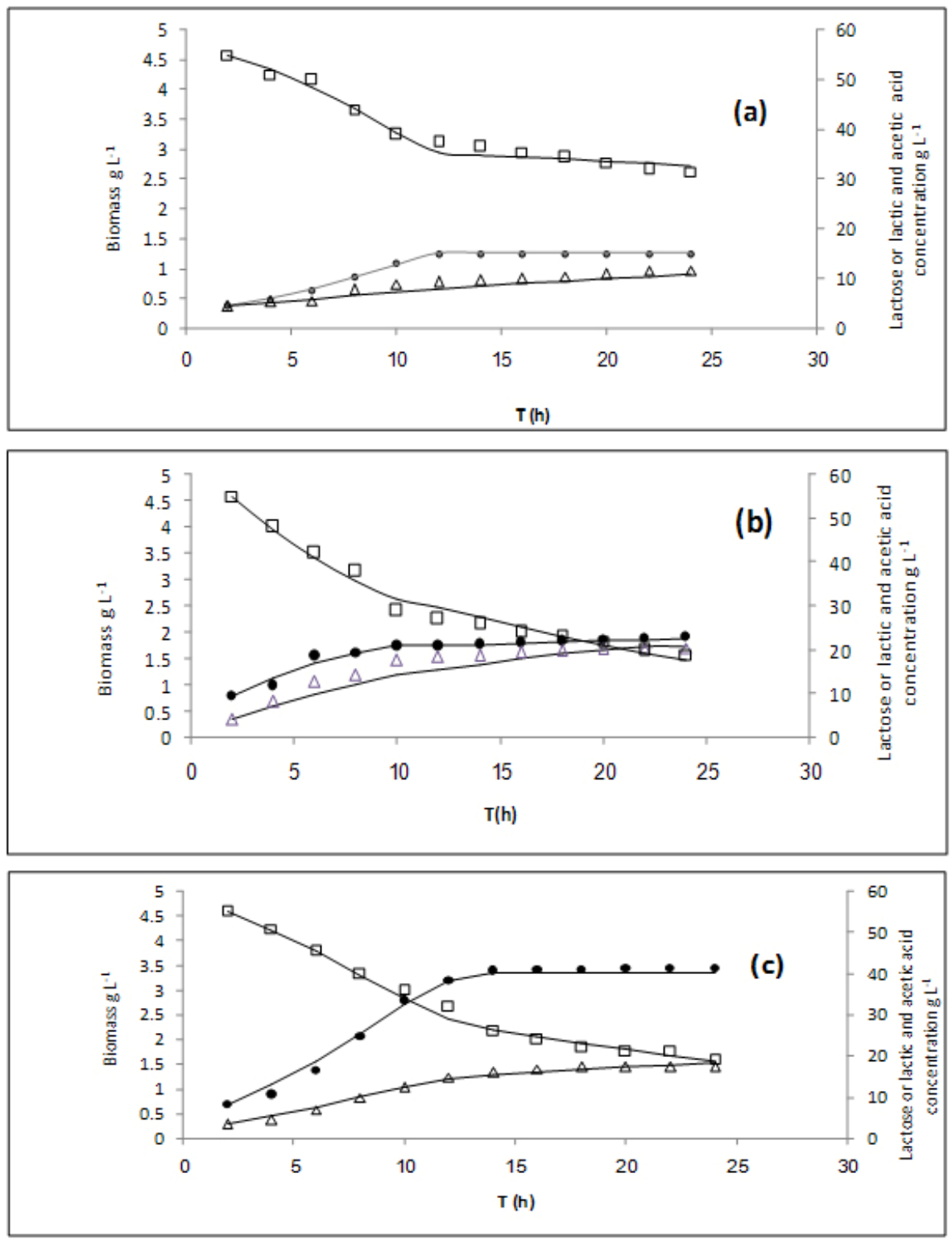

Figure 1. Mathematical simulation of three uncontrolled batch fermentation of free cell Bifidobacterium animalis subsp. lactis $\mathrm{Bb} 12$ in various media according to Table 1. Calculated data (continuous lines), experimental data: biomass concentration (•), lactic and acetic acid concentration $(\Delta)$, lactose concentration ( $\square$ ), (a) LCWP, (b) MCWP and (c) HCWP.

of the lactose content, its concentration was adjusted to 55 $\mathrm{g} \mathrm{L}^{-1}$ by adding lactose (Merck, Germany, Darmstadt).

\section{Immobilization techniques}

The method of (Audet et al. 1988) was used for Kcarrageenan-locust been gum (Fluka, USA) microencapsulation. Briefly, K-carrageenan-locust been gum powders by $2: 1$ ratio was prepared and suspended in $350 \mathrm{~mL}$ physiological saline $(0.85 \% \mathrm{NaC} 1)$ to produce a $3 \% \mathrm{w} / \mathrm{w}$ solution of total polymer. To dissolve the polymer, this solution was heated to $80^{\circ} \mathrm{C}$ with magnetic stirring. Following this process the solution was deaerated by autoclaving at $121^{\circ} \mathrm{C}$ for $15 \mathrm{~min}$. The solution was then cooled to $45^{\circ} \mathrm{C}$ and mixed with $7 \mathrm{~mL}$ concentrated $B$. animalis suspension under aseptic conditions. $650 \mathrm{~mL}$ sterile maize oil at $40^{\circ} \mathrm{C}$ was mixed with this mixture in stirred reactor at 700-1000 rpm for $2 \mathrm{~min}$. For gelation of small drop cell-polymer, the suspension was cooled to $25^{\circ} \mathrm{C}$. The formed bead was washed and soaked with $0.3 \mathrm{M}$ $\mathrm{KCl}$ sterile solution for $2 \mathrm{hrs}$. Separation of large beads with $0.5-1.0 \mathrm{~mm}$ diameter was done by adding $0.3 \mathrm{M} \mathrm{KC1}$ solution wet sieving.

The technique of (Krasaekoopt et al. 2004) with small modification was used for alginate-chitosan (Fluka, USA) 
microencapsulation. The cultures were suspended in $20 \mathrm{~mL}$ of sterile $0.1 \%$ peptone solution to prepare concentrated cell suspension, and $80 \mathrm{~mL}$ of $2 \%(\mathrm{w} / \mathrm{v})$ sterilized sodium alginate solution at $121^{\circ} \mathrm{C}$ for 15 min was mixed with the above cell suspension. The cell suspension was injected into sterile $0.05 \mathrm{M} \mathrm{CaCl}_{2}$ by $1 \mathrm{~mm}$ needle and formed bead remained $30 \mathrm{~min}$ in the same solution for gelation. The beads were rinsed and next kept in sterile $0.1 \%$ peptone solution at $4^{\circ} \mathrm{C}$.

Solution was prepared with dissolved $1.6 \mathrm{~g}$ low-molecularweight chitosan in $360 \mathrm{~mL}$ distilled water. Acidification was done by adding $0.4 \mathrm{~mL}$ of glacial acetic acid to achieve a final concentration of $0.4 \%(\mathrm{w} / \mathrm{v})$. The $\mathrm{pH}$ was then adjusted to 5.7-6 by adding $1 \mathrm{M} \mathrm{NaOH}$. The volume of solution was adjusted to $400 \mathrm{~mL}$ before autoclaving at $121^{\circ} \mathrm{C}$ for $15 \mathrm{~min}$. Then, $60 \mathrm{~g}$ of washed beads were submerged in $100 \mathrm{~mL}$ of chitosan solution and shaken at $100 \mathrm{rpm}$ for $40 \mathrm{~min}$ on an orbital shaker for coating. The chitosan-coated beads were washed and kept in $0.1 \%$ peptone solution at $4^{\circ} \mathrm{C}$.

For gellan-xanthan gum (Fluka, USA) immobilization, polymer powder was dispersed in $80^{\circ} \mathrm{C}$ deionized water by low stirring. This mixture was kept at $80^{\circ} \mathrm{C}$ for $1 \mathrm{hr}$. After this time, for complete hydration of the polymer, the temperature was raised to $90^{\circ} \mathrm{C}$. Solutions were next autoclaved for $15 \mathrm{~min}$ at $121^{\circ} \mathrm{C}$. Concentrated cell suspension prepared with $0.1 \%$ peptone water was then mixed with the above polymer solution. The polymer cell mixture was dropped by $1 \mathrm{~mm}$ needle to $0.1 \mathrm{M} \mathrm{CaCl}_{2}$ under low stirring. The formed beads were kept $1 \mathrm{hr}$ into $\mathrm{CaCl}_{2}$ solution for hardening.

\section{Culture conditions}

Free cells. Bifidobacterium animalis subsp. lactis $\mathrm{Bb} 12$ was propagated routinely at $37^{\circ} \mathrm{C}$ for $10-12 \mathrm{hrs}$ in MRS broth (Difco, Detroit, Mich) containing $0.5 \mathrm{~g} \mathrm{~L}^{-1}$ cysteine hydrochloride (Merck, Germany, Darmstadt) (Doleyres et al. 2002). This culture was incubated under anaerobic conditions (glass jar with gas pack); then $1 \mathrm{~mL}$ of active culture was used to inoculate $30 \mathrm{~mL}$ of the same culture media, and incubated $10-12 \mathrm{hrs}$ at $37^{\circ} \mathrm{C}$ under anaerobic conditions and then used as pre-culture.

A glass bioreactor (BIOFLO, New Brunswick Scientific Co., NJ, Edison USA) was used. After sterilization (at $121^{\circ} \mathrm{C}$ for $15 \mathrm{~min}$ ), the bioreactor was filled with $800 \mathrm{~mL}$ of heated medium $\left(5 \mathrm{~min}\right.$ at $121^{\circ} \mathrm{C}$, cooled for $5 \mathrm{hrs}$ at room temperature and reheated in the same conditions). The medium was then inoculated with $16 \mathrm{~mL}$ of pre-culture. The temperature was controlled at $37 \pm 1^{\circ} \mathrm{C}$, while $\mathrm{pH}$ was uncontrolled. Agitation was set to $60 \mathrm{rpm}$ and cultures were conducted in anaerobic condition with $\mathrm{CO}_{2}$ purged for 24 hrs. Samples were taken every $2 \mathrm{hrs}$.

Immobilized cells. $16 \mathrm{~mL}$ beads from each coated cells (measured by displacement in a $50 \mathrm{~mL}$ graduated cylinder) were separated and inoculated as pre-culture. Immobilized cells fermentation was performed in the same bioreactor containing HCWP medium and in the same conditions as free cells culture.

\section{Biomass determination}

Free cells. The method of (Desjardins et al. 1990) was used for the estimation of the biomass concentration.

Immobilized cells. The concentration of microbial cells in microencapsulated culture was measured by OD $620 \mathrm{~nm}$ units using visible spectrophotometer (Beckman coulter USA) after broken up beads using chemical and mechanical methods in combination (Zhou et al. 1998). For Kcarrageenan-locust been gum, collected beads were soaked in $0.85 \%$ saline solution and shaken with glass beads for 15 min at $45^{\circ} \mathrm{C}$ to suspend the immobilized cells (Audet et al. 1988). The absorbance of the mixture of cells and microcapsule broken up solution was measured at $620 \mathrm{~nm}$ and the biomass concentration was deduced from a calibration curve. Liquefied cell-free beads were used as reference for optical density measurement. For alginatechitosan beads, they were first blended for $1 \mathrm{~min}$ in stomacher and then stand $10 \mathrm{~min}$ in sterile solution citrate $(1 \% \mathrm{~W} / \mathrm{V})$ at $\mathrm{pH} 6.0$ and lightly shaken for dissolution (Krasaekoopt et al. 2004). Gellan-xanthan beads were softened in $0.1 \mathrm{M}$ sodium solution phosphate buffer, $\mathrm{pH} 7$ for $10 \mathrm{~min}$; blended process was then done with stomacher for $2 \mathrm{~min}$. Method for optical density and biomass calculation was as the same as $\mathrm{K}$-carrageenan-locust been gum procedure.

\section{High performance liquid chromatography}

The method of Tormo and Izco (2004) was used for the determination of organic acids (lactic and acetic acids) concentrations by HPLC analysis (Cecil 1100 U.K, Cambridge) with a $\mathrm{C}_{18}$ (Waters, USA) column, UV detector and gradient eluent. Lactose concentration was measured using the same HPLC system but with a Eurokat $\mathrm{H}$ column (Waters, USA) and RI detector at $65^{\circ} \mathrm{C}$ using water at $\mathrm{pH}=$ 2 as eluent. Flow rate was $1 \mathrm{~mL} \mathrm{~min}^{-1}$ and $\mathrm{pH}$ of water was adjusted by adding $\mathrm{H}_{2} \mathrm{SO}_{4}$ (Merck, Germany, Darmstadt).

\section{MODEL DEVELOPMENT}

\section{Growth kinetics}

The relation between specific growth rate $(\mu)$ and essential substrate concentration was given by the Monod equation:

$\mu=\mu_{\mathrm{m}}\left[\mathrm{s} /\left(\mathrm{K}_{\mathrm{S}}+\mathrm{s}\right)\right]$

[Equation 1]

Or:

$\mathrm{dx} / \mathrm{dt}=\mu_{\mathrm{m}}\left[\mathrm{s} /\left(\mathrm{K}_{\mathrm{S}}+\mathrm{s}\right)\right] \mathrm{x}$

[Equation 2] 
Table 1. Composition of the media used for B. animalis subsp. lactis Bb 12 culture.

\begin{tabular}{|l|c|c|c|}
\hline \multicolumn{1}{|c|}{ Media } & $\begin{array}{c}\text { Whey rehydrated percentage } \\
(\mathbf{v} / \mathbf{v})\end{array}$ & $\begin{array}{c}\text { Skim milk rehydrated } \\
\text { percentage }(\mathbf{v} / \mathbf{v})\end{array}$ & Yeast extract $\left(\mathbf{g ~ L}^{-1}\right)$ \\
\hline LCWP & 10 & 80 & 10 \\
\hline MCWP & 30 & 60 & 10 \\
\hline HCWP & 50 & 40 & 10 \\
\hline
\end{tabular}

$\mu_{\mathrm{m}}$ was the maximum achievable growth rate and $\mathrm{K}_{\mathrm{S}}$ was the Monod (substrate saturation) constant (Dutta et al. 1996).

Levenspiel proposed the following simple generalization of the Monod equation to account for the inhibitory product effect (Velizarov and Beschkov, 1998):

$\mathrm{dx} / \mathrm{dt}=\mu \mathrm{x}\left(1-\mathrm{p} / \mathrm{p}_{\mathrm{m}}\right)^{\mathrm{h}}$

\section{[Equation 3]}

$\mathrm{p}_{\mathrm{m}}$ and $\mathrm{h}$ were the maximum product concentration above which bacteria did not grow and the toxic power, respectively. This term characterized the manner in which the upper concentration limit is approached for the inhibitory product $\mathrm{p}_{\mathrm{m}}$. An increasing of the toxic power $\mathrm{h}$ led to an increase of the inhibitory effect. Therefore, equation 3 predicted a continuous decrease of the growth rate as product concentration rises. During Bifidobacterium growth, it could be assumed that inhibition resulted from the sum of lactic and acetic acid effects (Desjardins et al. 1990).

Lactic acid fermentation by L. delbrueckii indicated that the product formation kinetics combined growth-associated and non growth-associated contributions as follows (Altiok et al. 2006):

$\mathrm{dp} / \mathrm{dt}=\mathrm{Adx} / \mathrm{dt}+\mathrm{Bx}$

\section{[Equation 4]}

This two-parameter kinetics expression, often termed Luedeking-Piret kinetics, proved to be very useful in fitting product formation, not only for lactic acid fermentation, but for a wide range of fermentative organic acid productions. Monteagudo et al. (1997) developed Equation 5 involving a product inhibition factor as below:

$\mathrm{dp} / \mathrm{dt}=(\mathrm{Adx} / \mathrm{dt}+\mathrm{Bx})\left(1-\mathrm{p} / \mathrm{p}_{\mathrm{m}}{ }^{\prime}\right)$

[Equation 5]
This model may be improved by the addition of terms to express the dependence of the rate of lactic and acetic acids production on the inhibitory concentration as follows:

$\mathrm{dp} / \mathrm{dt}=(\mathrm{Adx} / \mathrm{dt}+\mathrm{Bx})\left(1-\mathrm{p}_{\mathrm{p}} \mathrm{p}_{\mathrm{m}}\right)^{\mathrm{f}}$

\section{[Equation 6]}

In this equation $\mathrm{p}_{\mathrm{m}}$, was the maximum product concentration above which bacteria did not product lactic and acetic acids and $f$ was the toxic power. An increase of the toxic power $f$ led to an increase of the inhibitory effect. Therefore, Equation 6 predicted a continuous decrease of the production rate as product concentration rose.

Stoichiometrically, the rate of substrate utilization was related to the biomass and product formation. Substrate consumption for maintenance was usually proposed to be first order as biomass concentration, $\mathrm{m}_{\mathrm{s}} \mathrm{x}$. So, the substrate utilization kinetic can be expressed as follows (Monteagudo et al. 1997):

$\mathrm{ds} / \mathrm{dt}=-\left(1 / \mathrm{Y}_{\mathrm{X} / \mathrm{S}}\right) \mathrm{dx} / \mathrm{dt}-\left(1 / \mathrm{Y}_{\mathrm{P} / \mathrm{S}}\right) \mathrm{dp} / \mathrm{dt}-\mathrm{m}_{\mathrm{S}} \mathrm{X}$

[Equation 7]

Bioreactor fermentations with two replicates for free cells and three replicates for immobilized cells were performed in order to determine the kinetic parameters of Equations 3, Equation 6 and Equation 7. Experimental data were fitted to Equations 3, Equation 6 and Equation 7 using a computer model program (Microsoft excel, 2007) and compared to batch fermentation data in order to minimize the difference between the calculated and the experimental values. Nonlinear regression analysis based on the Runge-Kutta method for differential equations was used to obtain the best fitting rate equations (Altiok et al. 2006). For comparison, the same procedure was applied to Equations 3, Equation 6 and Equation 7 without $\mathrm{h}$ and $\mathrm{f}$ toxic power, and the efficiency was compared based on total sum squares (Dutta et al. 1996). 

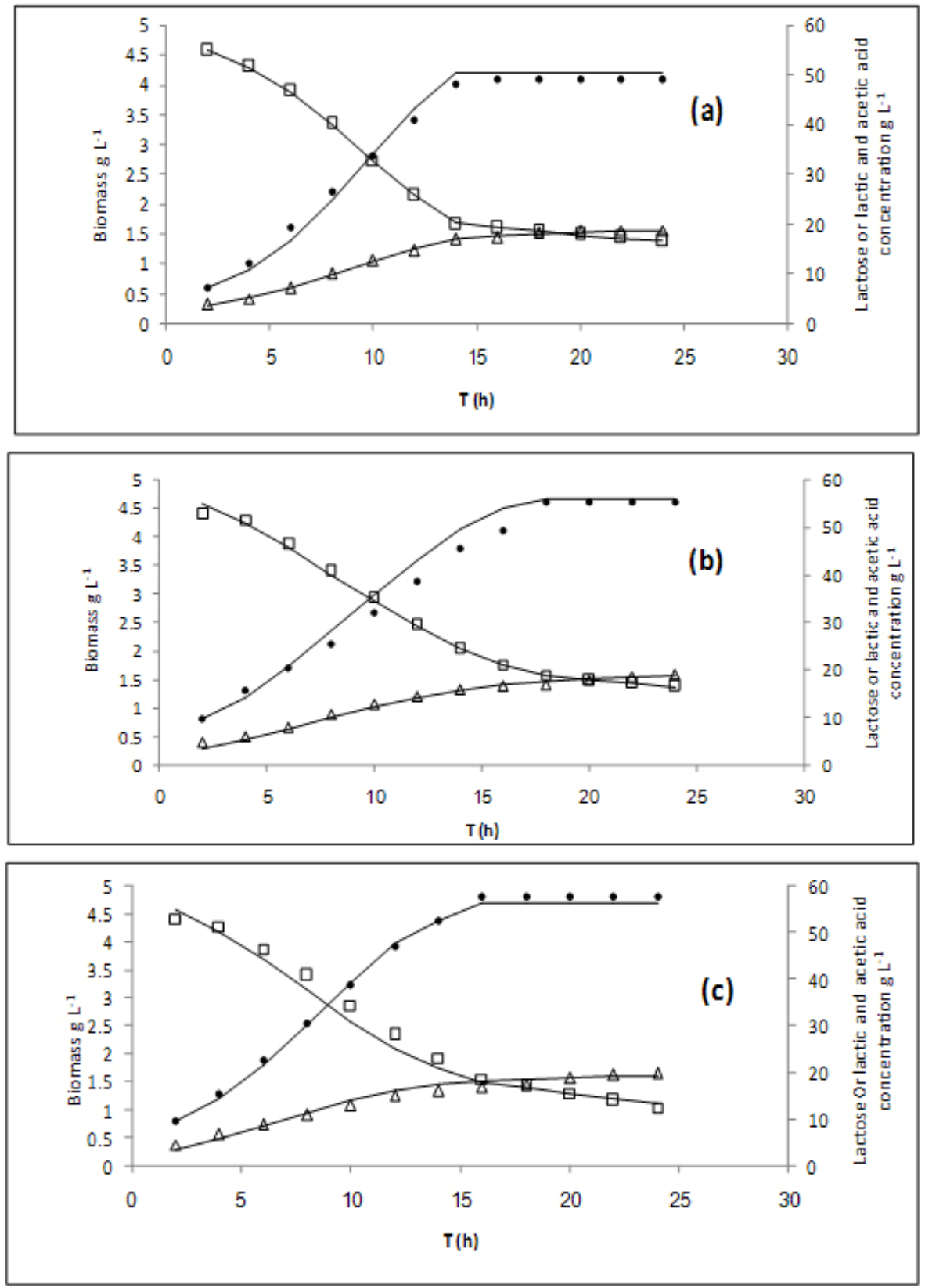

Figure 2. Mathematical simulation of three uncontrolled batch fermentation of immobilized Bifidobacterium animalis subsp. lactis Bb 12 cellsin 3 MWE medium. Calculated data (continuous lines), experimental data: biomass concentration ( $\bullet$ ), lactic and acetic acid concentration $(\Delta)$, lactose concentration ( $\square$ ). (a) gellan-xanthan, (b) Alginate-chitosan and (c) K-carageenan- locust been .

\section{Statistical analysis}

The Duncan Multiple Range test was used to compare the mean values in different treatments using SPSS software (version 16); the significance level used was $P<0.05$.

\section{RESULTS AND DISCUSSION}

Experimental and calculated data are shown in Figure 1 and Figure 2, and the corresponding estimated parameters are collected in Table 2 .

\section{Free cell kinetics}

Examination of the experimental data revealed that Equations 3, Equation 6 and Equation 7 can describe growth, acid production and substrate utilization kinetics (Figure 1). Table 2 shows that the addition of the toxic powers $\mathrm{h}$ and $\mathrm{f}$ clearly improved the fitting, since in all cases the addition of a toxic power led to lower total sum squares. $\mathrm{x}_{\mathrm{m}}, \mathrm{K}_{\mathrm{S}}$ and $\mu_{\mathrm{m}}$ increased for increasing whey permeate concentration (Table 2). The toxic power $h$ for growth kinetic appeared affected by media composition. 
Irrespective of the medium used, lactose was not the limiting substrate owing to the large residual amounts (Figure 1), and hence the "usable" nitrogen was most likely the limiting factor (Amrane and Prigent, 1997), especially in LCWP medium. Consequently, minimum culture parameter values (amount of biomass $\mathrm{x}, \mu_{\mathrm{m}}, \mathrm{Y}_{\mathrm{X} / \mathrm{S}}$, product yield coefficient (g lactic and acetic acid $\left.\mathrm{g}^{-1}\right)\left(\mathrm{Y}_{\mathrm{P} / \mathrm{S}}\right), \mathrm{h}$, growth-associated product formation coefficient ( $\mathrm{g}$ lactic and acetic acid g ${ }^{-1}$ biomass) (A) and product concentration p) belonged to this medium. Maximum $h$ value (1.1) was found for MCWP medium. This increase of the $h$ value illustrated a greater organic acid inhibition effect in the case of growth. In lactic acid bacteria, substrate limitation leads to disturbance between catabolism and anabolism, resulting in a shift from anabolism to catabolism (Garrigues et al. 2001). This phenomenon corresponds to a direct use of the available energy towards maintenance rather than growth for Bifidobacteria, and hence this shift causes an increase of the production of acids, which resulted in the dissipation of the proton gradient that is maintained across the cell membrane, and hence bacteria require maintenance energy to regulate this $\mathrm{pH}$ gradient (Beal and Corrieu, 1995). MCWP whey protein content was higher than LCWP (Table 1), however not at a level which allowed avoiding any nutritional limitation. Consequently, higher $\mathrm{h}, \mathrm{A}$, nongrowth-associated product formation coefficient (g lactic and acetic acid $\mathrm{g}$ biomass $\left.^{-1}\right)(\mathrm{B})$, maintenance coefficient ( $\mathrm{g}$ lactose $\mathrm{g}^{-1}$ biomass $\left.\mathrm{h}^{-1}\right)\left(\mathrm{m}_{\mathrm{s}}\right)$, lactic and acetic acid concentrations and $\mathrm{Y}_{\mathrm{P} / \mathrm{S}}$ values were recorded for MCWP medium (Table 2 and Figure 1). High concentrations of hydrogen ions that are in part supplied by the acidic metabolic products like lactic and acetic acids functioning as auto inhibitors and proliferation of these products caused a decrease of the growth kinetics (Akerberg et al. 1998). Some researchers reported that initial lactate and acetate concentrations above $10 \mathrm{~g} \mathrm{~L}^{-1}$ caused a rapid decrease of the growth rate of $B$. longurn YT 4021, or cessation of growth occurred in media containing more than $18 \mathrm{~g} \mathrm{~L}^{-1}$ both lactate and acetate (Desjardins et al. 1990). According to our results, the $\mathrm{p}_{\mathrm{m}}$ value varied with the medium used (Table 2). Variation in $\mathrm{p}_{\mathrm{m}}$ can be related to the redox potential. Skim milk and whey permeate have sulfurcontaining amino acids and liberates these amino acids during heat treatment, which could decrease media redox potential and neutralize acidic inhibitory effect (Dave and Shah, 1998). Modifying these amounts can cause modifications of the redox potential, and hence the higher $\mathrm{p}_{\mathrm{m}}$ value was most likely related to the higher redox potential. Moreover, whey permeate contains available nitrogen component considered as promote growth factor for Bifidobacteriaum (Janer et al. 2004). Subsequently, higher $\mathrm{x}_{\mathrm{m}}, \mu_{\mathrm{m}}, \mathrm{K}_{\mathrm{S}}, \mathrm{Y}_{\mathrm{X} / \mathrm{S}}$ and log phase belonged to HCWP medium which contained the higher whey concentration (Table 2 and Figure 1).

Similarly to growth (factor $\mathrm{h}$ ), the toxic power factor $\mathrm{f}$ for production appeared also affected by media composition. Similarly to growth, MCWP led to the higher $f$ value. Lower $\mathrm{f}$ values if compared to the $\mathrm{h}$ values indicated that lactic and acetic acid concentrations had lower inhibitory effect on acid production than growth. To our knowledge, the effect of organic acids on cessation of acid production during Bifidobacteria growth has not been reported in the available literature. Organic acids (lactic and acetic acids) production took place not only during growth but also during the stationary phase, even though in lower amounts, as can be seen in Table 2 and Figure 1. From Table 2, the ratio of the growth- and non growth-associated production A/B were 5, 8 and 25 for LCWP, MCWP and HCWP respectively, showing that larger amounts of lactic and acetic acids were produced during growth if compared to stationary phase; contrarily, (Desjardins et al. 1990) reported $70 \%-75 \%$ lactic and acetic acids produced during stationary phase of Bifidobacteria culture. The higher A and $B$ values were 4 and 0.5 recorded during growth on MCWP. Irrespective of the medium used, final production $\mathrm{p}_{\mathrm{m}}{ }_{\mathrm{m}}$ occurred in the late stage of the stationary phase and the higher value belonged to MCWP medium.

Substrate concentration time-courses are also shown in Figure 1. The model (Equation 7) was found to match experimental data. Fairly similar amounts of organic acids and biomass were produced during culture on MCWP and HCWP media (Figure 1b and Figure 1c), leading to nearly similar lactose consumption found for both media, while this consumption decreased for LMWE (Figure 1a).

\section{Immobilized cell kinetics}

Assessment of experimental data revealed that the model can also depict immobilized cell growth, acid production and substrate utilization time-courses (Figure 2). Encapsulation protect microorganism from its environment and the link between the microbial environment and cell growth was highlighted by the model. Similarly to free cells culture, the absence of toxic power in the model led to higher total sum squares (Table 2). Kinetic parameter values varied compared to free cells growing on HCWP medium and also varied with the type of coating material. Both toxic powers $h$ and $f$ increased in the same way: Gellan xanthan < Alginate chitosan $<$ K-Carageenan-locust been. These variations could have two reasons: 1- As a result of widespread surface growth, cells are continuously released from the gel bead into the fermentation medium, leading to decreasing cell population in the beads (Dembczynski and Jankowski, 2002) and hence a higher biomass release from a microcapsule resulted in lower cells amount inside the beads. However, results showed negligible release from immobilized cells after $24 \mathrm{hrs}$ culture, irrespective of the coating material used. 2- It has been reported for alginate beads with entrapped L. lactis that the $\mathrm{pH}$ gradient was caused by lactic acid accumulation inside beads, leading to the inactivation of cells in the core of the beads (Klinkenberg et al. 2001). Therefore, coating materials with more protection against external components results in a lower permeability for external and internal mass transfer and hence a higher inside inhibition factor, leading to a smaller amount of biomass produced. In this 
study, the latter reason could be assumed for the observed disparities between coating materials. However, from the amounts of acids produced during growth and stationary phases (Figure 2), it can be concluded in an absence of shift of cell metabolism from anabolism to catabolism due to the effect of the above factors owing to the low $\mathrm{B}$ values and hence the low maintenance production (Table 2) (Garrigues et al. 2001; van Bodegom, 2007). As a result gellan-xanthat had less permeability for external and internal mass transfer in this medium compare to the other biopolymers, leading to the lowest parameter values, $\mathrm{x}_{\mathrm{m}}, \mu_{\mathrm{m}}, \mathrm{h}$ and $\mathrm{K}_{\mathrm{S}}$. The permeability of the K-carageenan-locust was higher, leading to the highest $\mathrm{x}_{\mathrm{m}}, \mu_{\mathrm{m}}$ and $\mathrm{K}_{\mathrm{S}}$ values (Table 2). Audet et al. (1988) reported that $S$. salivarius subsp. thermophilis entrapped in k-carageenan-locust been showed long log phase compare to free cells, while immobilized and free Lactobacillus delbrueckii subsp. bulgaricus cells showed similar log phases. The present work showed greater $\log$ phase for immobilized cells if compared to HCWP free cells. Coating materials did not affect final acids production, leading to similar $\mathrm{p}_{\mathrm{m}}$ values recorded for all coating material types.

As was the case for free cells, an inhibitory effect of $\mathrm{p}_{\mathrm{m}}$ occurred at late stationary phase. As for the $h$ parameter, biopolymers permeability had also an effect on the f toxic power, (Table 2). From this, gellan-xanthan showed the lowest $\mathrm{f}$ toxic power and $\mathrm{k}$-carageenan-locust been beads showed the higher $\mathrm{f}$ value (Table 2). Medium composition can affect the structure of the biopolymer. Audet et al. (1988) reported that alginate gels suffer from instability with phosphate and lactate ions, since calcium ion that stabilized the gel move with lactate during lactic acid bacteria fermentation. This change in structure and accordingly physical properties of biopolymers can occur during cultures without $\mathrm{pH}$ control on complex media as it was the case in this work. Therefore permeability of biopolymers changed during fermentation and at late stage of stationary phase an accumulation of deleterious factors inside beads can cause cessation of lactic and acetic acids production. As a result k-carageenan-locust been showed the higher $\mathrm{A} / \mathrm{B}$ ratio, while similar $\mathrm{A} / \mathrm{B}$ ratio was recorded for gellan-xanthan and alginate-chitosan (Table 2). High $\mathrm{A} / \mathrm{B}$ ratios indicated small amount of organic acids produced at stationary phase if compared to free cells (Table 2), in agreement with the comparison of Figure 1c and Figure 2. Contrarily, Morin et al. (1992) reported uncoupling for growth and lactic acid production occurring in Lactococcus lactis subsp. cremoris encapsulated in calcium alginate beads. It can be noted that nearly similar amounts of acids were produced for all coating materials used (Figure 2).

$\mathrm{Y}_{\mathrm{X} / \mathrm{S}}$ and $\mathrm{Y}_{\mathrm{P} / \mathrm{S}}$ values did not varied really significantly with the biopolymer used (Table 2). The $\mathrm{m}_{\mathrm{s}}$ factor is related to the non-growth metabolism (Garrigues et al. 2001; van

Table 2. Culture parameters for free and immobilized Bifidobacterium animalis subsp. lactis $\mathrm{Bb} 12$ cells growing without $\mathrm{pH}$ control ht uppercase letters indicate differences between free cell mediaLCWP, MCWP and HCWP, while left uppercase letters indicate differences between HCWP free cell culture and immobilized cell cultures witha significance level $P<0.05$.

\begin{tabular}{|c|c|c|c|c|c|c|c|c|c|c|c|c|c|c|c|c|}
\hline & h & f & A & B & $\mathbf{Y}_{\mathrm{X} / \mathrm{s}}$ & $\mathrm{Y}_{\mathrm{P} / \mathrm{S}}$ & m & $\mathrm{K}_{\mathbf{s}}$ & $\mu_{m}$ & $p_{m} g^{-1}$ & $p_{m}^{\prime} g^{-1}$ & $\mathbf{x}_{\mathrm{m}} \mathrm{g} \mathrm{L}^{-1}$ & \multicolumn{4}{|c|}{ Total sum square } \\
\hline & & & & & & & & & & & & & \multicolumn{4}{|c|}{ Toxic power } \\
\hline & & & & & & & & & & & & & & Nith & & thout \\
\hline \multirow[t]{2}{*}{ Media } & & & & & & & & & & & & & Biomass & $\begin{array}{c}\text { Acids } \\
\text { production }\end{array}$ & Biomass & $\begin{array}{c}\text { Acids } \\
\text { production }\end{array}$ \\
\hline & & & & & & & Free cell & & & & & & & & & \\
\hline LCWP & $0.3^{\mathrm{d}}$ & $0^{c}$ & $1^{c}$ & $0.2^{\mathrm{b}}$ & $0.05^{b}$ & $0.5^{\mathrm{b}}$ & $0.02^{\mathrm{c}}$ & $0.8^{\mathrm{b}}$ & 0.2 & 9.35 & $11.7^{\mathrm{a}}$ & $1.25^{\mathrm{a}}$ & $3.8 \times 10^{-4}$ & 1.04 & $2 \times 10^{-2}$ & 1.9 \\
\hline MCWP & $1.1^{\mathrm{a}}$ & $0.2^{\mathrm{a}}$ & $4^{a}$ & $0.5^{\mathrm{a}}$ & $0.06^{b}$ & $0.57^{\mathrm{a}}$ & $0.24^{\mathrm{a}}$ & $1^{\mathrm{a}}$ & 0.28 & 17.7 & $20.5^{\mathrm{b}}$ & $1.92^{\mathrm{b}}$ & $3.7 \times 10^{-3}$ & 1.8 & $1.4 \times 10^{-1}$ & 3.7 \\
\hline \multirow[t]{2}{*}{ HCWP } & ${ }^{\mathrm{a}} 0.95^{\mathrm{b}}$ & ${ }^{c} 0.1^{b}$ & $3^{b}$ & $0.12^{b}$ & ${ }^{\mathrm{c}} 0.1^{\mathrm{a}}$ & ${ }^{b} 0.49^{b}$ & ${ }^{a} 0.15^{b}$ & ${ }^{\mathrm{b}} 1.1^{\mathrm{a}}$ & 0.36 & ${ }^{\mathrm{b}} 16.2$ & ${ }^{c} 17.6^{c}$ & ${ }^{c} 3.45^{c}$ & $8.3 \times 10^{-3}$ & 0.3 & $2 \times 10^{-1}$ & 4.2 \\
\hline & & & & & & & $\begin{array}{l}\text { Immobilized } \\
\text { cell }\end{array}$ & & & & & & & & & \\
\hline $\begin{array}{c}\text { Gellan } \\
\text { Xanthan }\end{array}$ & ${ }^{\circ} 0.55$ & $\mathrm{~b} 0.2$ & $\mathrm{~b}_{3}$ & ${ }^{b} 0.1$ & ${ }^{\mathrm{bc}} 0.11$ & ${ }^{a} 0.49$ & ${ }^{\circ} 0.04$ & $\mathrm{~b}_{1} 1.1$ & 0.3 & ${ }^{a} 16.9$ & $\mathrm{~b}_{19}$ & ${ }^{\mathrm{b}} 4.1$ & $1.7 \times 10^{-2}$ & $4 \times 10^{-2}$ & $6.4 \times 10^{-1}$ & 1.7 \\
\hline $\begin{array}{l}\text { Alginate } \\
\text { chitosan }\end{array}$ & ${ }^{\circ} 0.6$ & ${ }^{\mathrm{b}} 0.3$ & $b_{3}$ & ${ }^{b} 0.1$ & ab 0.12 & ${ }^{a} 0.5$ & ${ }^{\mathrm{d}} 0.06$ & ${ }^{b} 1.2$ & 0.28 & $\mathrm{a}_{17}$ & ${ }^{\mathrm{b}} 19.2$ & ${ }^{\mathrm{a}} 4.6$ & $4.9 \times 10^{-2}$ & $3.6 \times 10^{-1}$ & $7.5 \times 10^{-1}$ & 1.8 \\
\hline $\begin{array}{l}\text { carageenan- } \\
\text { locust been }\end{array}$ & ${ }^{b} 0.75$ & a 0.5 & ${ }^{a} 4$ & ${ }^{b} 0.1$ & ${ }^{\mathrm{ab}} 0.13$ & ${ }^{\mathrm{ab}} 0.47$ & ${ }^{\mathrm{b}} 0.08$ & $\mathrm{a}_{1.5}$ & 0.34 & $\mathrm{a}_{17}$ & ${ }^{\mathrm{a}} 19.8$ & ${ }^{\mathrm{a}} 4.8$ & $6.7 \times 10^{-3}$ & $8.3 \times 10^{-1}$ & $5.7 \times 10^{-1}$ & 2.8 \\
\hline
\end{tabular}


Bodegom, 2007) and hence maximum stationary acid production (2.8 $\mathrm{g} \mathrm{L}^{-1}$ - Figure 2) was found for $\mathrm{K}$ carageenan-locust been beads owing to the higher $\mathrm{m}_{\mathrm{s}}$ value recorded (Table 2). This phenomenon can be related to the decrease of K-Carageenan-locust been permeability at late stage of fermentation. For the three tested coating materials the $m_{s}$ values were lower than those found during free cells culture, showing the protection effect of the coating materials (Table 2).

\section{CONCLUDING REMARKS}

A model was developed and validated for free and immobilized cells growth, total acid production and substrate utilization. The biomass and production model was considered advantageous since the inhibitory effect could be adjusted by modifying the toxic powers which are affected by environmental conditions, and hence the model appeared applicable for a wide range of culture conditions. Kinetic analysis showed differences in behavior between free and immobilized cells. Indeed, medium composition and the type of coating material affected significantly kinetic data, and hence the appeared helpful for primary estimation of nutrition limitations or the suitability of coating materials against deleterious factors. However, further studies are needed dealing with physical properties of biopolymers as coating materials and the modifications of their properties during fermentation in complex media with or without $\mathrm{pH}$ control. The above results showed that for increasing protect effect of coating materials against environmental deleterious factors, transport limitation occurred, which is disadvantageous for cell formation. New methods to produce applicable coating materials appear therefore as an important task.

\section{REFERENCES}

AKERBERG, C.K.; HOFVENDAHL, K.; ZACCHI, G. and HAHN-HÄGERDAL, A.B. Modelling the influence of $\mathrm{pH}$, temperature, glucose and lactic acid concentrations on the kinetics of lactic acid production by Lactococcus lactis ssp. lactis ATCC 19435 in whole-wheat flour. Applied Microbiology and Biotechnology, June 1998, vol. 49, no. 6, p. 682-690.

ALTIOK, Duygu; TOKATLI, Figen and HARSA, Sebnem. Kinetic modeling of lactic acid production from whey by Lactobacillus casei (NRRL B-441). Journal of Chemical Technology and Biotechnology, July 2006, vol. 81, no. 7, p. 1190-1197.

AMRANE, Abdeltif and PRIGENT, Yves. Growth and lactic acid production coupling for Lactobacillus helveticus cultivated on supplemented whey: influence of peptidic nitrogen deficiency. Journal of Biotechnology, May 1997, vol. 55 , no. 1, p. 1-8.

AUDET, Pascal; PAGUIN, Céline and LACROIX, Christophe. Immobilized growing lactic acid bacteria with k-carrageenan - locust bean gum gel. Applied Microbiology and Biotechnology, August 1988, vol. 29, no. 1, p. 11-18.

BALANNEC, Beatrice; BOUGUETTOUCHA, Abdellah and AMRANE, Abdeltif. Unstructured model for batch cultures without $\mathrm{pH}$ control of Lactobacillus helveticusInhibitory effect of the undissociated lactic acid. Biochemical Engineering Journal, August 2007, vol. 35, no. 3, p. 289-294.

BEAL, Catherine and CORRIEU, Georges. On-line indirect measurements of biological variables and their kinetics during $\mathrm{pH}$ controlled batch cultures of thermophilic lactic acid bacteria. Journal of Food Engineering, 1995, vol. 26, no. 4 , p. 511-525.

BOZANIC, Rajka and TRATNIK, Ljubica. Quality of cow's and goat's fermented Bifido milk during storage. Food Technology Biotechnology, October-December 2001, vol. 39, no. 2, p. 109-114.

DAVE, R.I. and SHAH, N.P. Ingredient supplementation effects on viability of probiotic bacteria in yogurt. Journal of Dairy Science, December 1998, vol. 81, no. 11, p. 28042816.

DEMBCZYNSKI, R. and JANKOWSKI, T. Growth characteristics and acidifying activity of Lactobacillus rhamnosus in alginate/starch liquid-core capsules. Enzyme and Microbial Technology, July 2002, vol. 31, no. 1-2, p. 111-115.

DESJARDINS, Marie-Line; ROY, Denis; TOUPIN, Christian and GOULET, Jacques. Uncoupling of growth and acids production in Bifidobacterium ssp. Journal of Dairy Science, June 1990, vol. 73, no. 6, p. 1478-1484.

DOLEYRES, Y.; PAGUIN, C.; LEROY, M. and LACROIX, C. Bifidobacterium longum ATCC 15707 cell production during free- and immobilized-cell cultures in MRS-whey permeate medium. Applied Microbiology and Biotechnology, October 2002, vol. 60, no. 1-2, p. 168-173.

DOLEYRES, Y. and LACROIX, C. Technologies with free and immobilized cells for probiotic bifidobacteria production and protection. International Dairy Journal, October 2005, vol. 15, no. 10, p. 973-988.

DUNNE, Colum and SHANAHAN, Fergus. Role of probiotics in the treatment of intestinal infections and inflammation. Current Opinion in Gastroenterology, January 2002, vol. 18, no. 1, p. 40-45.

DUTTA, S.K.; MUKHERJEE, A. and CHAKRABORTY, P. Effect of product inhibition on lactic acid fermentation: simulation and modeling. Applied Microbiology and Biotechnoloy, November 1996, vol. 46, no. 4, p. 410-413.

GARRIGUES, Christel; MERCADE, Myriam; COCAIGNBOUSQUET, Muriel; LINDLEY, Nic D. and LOUBIERE, 
Pascal. Regulation of pyruvate metabolism in Lactococcus lactis depends on the imbalance between catabolism and anabolism. Biotechnology and Bioengineering, July 2001, vol. 74, no. 2, p. 108-115.

GHALY, A.E.; TANGO, M.S.A. and ADAMS, M.A. Enhanced lactic acid production from cheese whey with nutrient supplement addition. Journal of Scientific Research and Development, May 2003, vol. V, p. 1-20.

GOMES, Ana M.P. and MALCATA, F. Xavier. Bifidobacterium spp. and Lactobacillus acidophilus: biological, biochemical, technological and therapeutical properties relevant for use as probiotics. Trends in Food Science \& Technology, April 1999, vol. 10, no. 4-5, p. 139157.

JANER, C.; PELAEZ, C. and REQUENA, T. Caseinomacropeptide and whey protein concentrate enhance Bifidobacterium lactis growth in milk. Food Chemistry, June 2004, vol. 86, no. 2, p. 263-267.

JANER, C.; ARIGONI, F.; LEE, B.H.; PELAEZ, C. and REQUENA, T. Enzymatic ability of Bifidobacterium animalis subsp. lactis to hydrolyze milk proteins: identification and characterization of endopeptidase $\mathrm{O}$. Applied and Environmental Microbiology, December 2005, vol. 71 , no. 12 , p. $8460-8465$.

KLINKENBERG, G.; LYSTAD, K.Q.; LEVINE, D.W. and DYRSET, N. pH-controlled cell release and biomass distribution of alginate-immobilized Lactococcus lactis subsp. lactis. Journal of Applied Microbiology, October 2001, vol. 91, no. 4, p. 705-714.

KRASAEKOOPT, Wunwisa; BHANDARI, Bhesh and DEETH, Hilton. The influence of coating materials on some properties of alginate beads and survivability of microencapsulated probiotic bacteria. International Dairy Journal, August 2004, vol. 14, no. 8, p. 737-743.

MACFARLANE, George T. and MACFARLANE, Sandra. Human colonic microbiota: ecology, physiology and metabolic potential of intestinal bacteria. Scandinavian Journal of Gastroenterology, May 1997, vol. 32, supl. 222, p. 3-9.

MONTEAGUDO, Jose M.; RODRÍGUEZ, Lourdes; RINCÓN, Jesusa and FUERTES, Juan. Kinetics of lactic acid fermentation by Lactobacillus delbrueckii grown on beet molasses. Journal of Chemical Technology and Biotechnology, March 1997, vol. 68, no. 3, p. 271-276.

MORIN, Nicole; BERNIER-CARDOU, Michèle and CHAMPAGNE, Claude P. Production of concentrated Lactococcus lactis subsp. cremoris suspension in calcium alginate beads. Applied and Environmental Microbiology, February 1992, vol. 58, no. 2, p. 545-550.
TORMO, M. and IZCO, J.M. Alternative reversed-phase high-performance liquid chromatography method to analyses organic acids in dairy products. Journal of Chromatography A, April 2004, vol. 1033, no. 2, p. 305310 .

VAN BODEGOM, Peter. Microbial maintenance: a critical review on its quantification. Microbial Ecology, May 2007, vol. 53, no. 4, p. 513-523.

VAN DER MEULEN, Roel; ADRIANY, Tom; VERBRUGGHE, Kristof and DE VUYST, Luc. Kinetic analysis of bifidobacterial metabolism reveals a minor role for succinic acid in the regeneration of $\mathrm{NAD}^{+}$through its growth-associated production. Applied and Environmental Microbiology, August 2006, vol. 72, no. 8, p. 5204-5210.

VELIZAROV, S. and BESCHKOV, V. Biotransformation of glucose to free gluconic acid by Gluconobacter oxydans: substrate and product inhibition situations. Process Biochemistry, June 1998, vol. 33, no. 5, p. 527-534.

ZHOU, Y.; MARTINS, E.; GROBOILLOT, A.; CHAMPAGNE, C.P. and NEUFELD, R.J. Spectrophotometric quantification of lactic bacteria in alginate and control of cell release with chitosan coating. Journal of Applied Microbiology, March 1998, vol. 84, no. 3, p. 342-348. 